\title{
Speaking skill of elementary school students reviewed by gender
}

\author{
Elnida Saldaria ${ }^{1}$, Vina Anggia Nastitie Ariawan ${ }^{2 *}$, Isah Cahyani ${ }^{3}$ \\ ${ }^{1}$ SD Negeri 012 Lipatkain. Jalan Datuk Harunsyah, Lipat Kain, Kampar Kiri, Riau 28471, Indonesia \\ ${ }^{2}$ STKIP Majenang. Jalan Raya Pahonjean Km. 2 Majenang Kab. Cilacap Jawa Tengah, Indonesia \\ ${ }^{3}$ Universitas Pendidikan Indonesia. Jalan DR. Setiabudi No.229, Isola, Sukasari, Kota Bandung, Jawa \\ Barat 40154, Indonesia \\ * Corresponding Author. E-mail: vivianatsir@gmail.com \\ Received: 16 July 2018; Revised: 10 January 2019; Accepted: 8 February 2019
}

\begin{abstract}
Speaking skill is one of language skill that used on daily life. Speaking skill include two aspects namely linguistic aspect and non-linguistic aspect. However, not all people have good speaking skill when facing some situation. That condition is available to students on language learning. Every students has difference obstacles on speaking. The obstacles of students' speaking skill can be identified by speaking aspects. This research aims to identifying gender difference of students' speaking skill on elementary schools. This research was using quantitative design within expost facto method. Technique of collecting sample used stratified sampling. Samples of this research were 30 students of third grade at one of elementary schools on Kampar Sub-District. Technique of collecting data in this research used speaking test. Technique of validity data used content validity and the validity was done by an expert or obtain expert judgement. Meanwhile, the data analysis used inference statistic. The result of this research useful to identify students' speaking skill so teacher can give appropriate treatment to improve students' speaking skill based on their necessities.
\end{abstract}

Keywords: gender, speaking skill, elementary school, student.

How to Cite: Saldaria, E., Ariawan, V., \& Cahyani, I. (2019). Speaking skill of elementary students reviewed by gender. Jurnal Prima Edukasia, 7(1), 20-27. doi:https://doi.org/10.21831/jpe.v7i1.20363

do

https://doi.org/10.21831/jpe.v7i1.20363

\section{Introduction}

Speaking is one manifestation of oral communication that is used to provide information through words spoken through a spoken tool. Speaking is a ways to communicate ideas that are compiled and developed according to the needs of listeners. Speaking requires at least two people so an interaction emerges. Speaking skill occupy an important position in language learning because speaking skill symbolize students' communicative skill. In other words, speaking skill not only play a role in language learning but play an important role in the others. This means that one indicator of the success of student learning is the skill to express ideas orally in a subject area (Abidin, 2015).

It has become a common thing to find students who do not understand the teacher's explanation. The students do not dare to express their opinions, or they are more concerned about a student not being able to take part in class learning. This is a small part of the problems faced by students and teachers at school and almost occurs at every level of education. These problems cause students to have low speaking skill that have an impact on their communication skill (Westgate \& Hughes, 2015, pp. 565). In everyday life, a person communicates orally more than he or she does in other ways. Speaking skill become an important skill which must be developed in the global era which is full of challenges and problems (Piirto, 2011; Mulyasa, 2012; Buckley, 2003). Speaking is the skill of articulating sounds or words to express, state, and convey thoughts, ideas, and feelings (Tarigan, 2013). As a form, speaking is called as a tool to communicate arranged or developed ideas in accordance with the needs of the listener. Essentially, speaking is an expression of one's thoughts and feelings in the form of linguistic sounds. This encouragement begins with instinct, mind, and thinking (Ciptarja, 2008).

The realization of meaningful learning is regarded by students' speaking skill. Speaking skill is one aspect that must be developed in 
Jurnal Prima Edukasia, 7 (1), 2019 -21

Elnida Saldaria, Vina Anggia Nastitie Ariawan, Isah Cahyani

elementary school. Students are trained to be able to use and express their thoughts by using the right words and sentences. The development of speaking skill in elementary school students emphasizes more on the selection of words (diction), word wrangling, intonation of reading sentences and expressions (Permana, 2015).

Speaking skill is a skill to speak words to express thoughts, ideas, and feelings. Speaking is one form of communication in the language. Speaking is not only done in formal education. More than that, speaking skill is very important in the life of society. Having speaking skill is not as easy as one might imagine. Many skilled students pour out their feelings in written form, but are less skilled at presenting them verbally (Thompson \& Haddock, 2012).

Naturally, a person is able to speak. However, in formal situations nervousness arises often, so that the proposed idea becomes irregular and then the language becomes irregular as well. Some people even do not dare by itself to speak (Boyce, 2007). The presumption that every person automatically can speak has led to the ignoration of coaching of this speaking skill (Tsou, 2005).

The low level of speaking skill can be caused by a lack of listening skill to students so that they do not capture the information received by the teacher. In addition, low speaking skill can also be triggered by the presentation of learning given by the teacher and the low level of teacher speaking skill (Westgate \& Hughes, 2015 pp. 566).

In accordance with that, teacher as the central figure should design the teaching-learning program based on the relevant approach. Teaching and learning activities can make students actively experience the learning to talk properly. This is important to discuss because at elementary school students receive the laying of the basics of speaking so that it can trigger students to practice speaking (Azarfam \& Baki, 2012). Through learning in school, students can be skilled at speaking inside the classroom and outside the classroom. Students are required to develop speaking skill in their daily lives such as in the family or in the neighborhood (Stanley \& Dillingham, 2012).

Learning is a reciprocal process that is carried out interactively between the teacher and students and students with students. The reciprocal process in the form of information provided by the teacher can be understood and responded to by students so that learning can achieve the intended goals. However, in every learning there is often minimal interaction between teachers and students. The lack of a portion of students to speak causes the opportunity of students' speaking skill to develop to be low (Alexander, 2012).

Based on the constructivism theory proposed by Vygotsky, students will not speak fluently when they do not have the opportunity to speak even though one way for students to be able to develop their social skill is by talking or communicating. As good as structuring the classroom if the teacher is unable to facilitate the development of students' speaking, then the results will not be effective (Hardman, 2008).

Each student has different speaking skill so that teachers need to pay attention to student characteristics. If the teacher has understood the characteristics of students then the teacher can design the right learning (Chappell, 2014). Therefore, before starting the lesson the teacher should be able to identify the students' weaknesses through initial speaking test. This study aims to identify speaking skill between female students and male students. Researchers will compare students' speaking skill based on aspects of speaking skill (Hwang, et al., 2016).

\section{Method}

This research used quantitative research method with expost facto research design. The expost facto research is a research in which the independent variables have occurred when the researchers started with observing the dependent variables in a research (Darmadi, 2011).

Methodically, expost facto research is a research which tests the hypothesis but does not provide certain treatment for a cause to provide treatment or manipulation (Sugiyono, 2013). Sample selection technique used in this study was stratified sampling. Stratified sampling is a sampling technique in which the population is grouped in a certain stratum and then sampled with a balanced proportion (Suharsaputra, 2014). The stages used in this study were reviewed by gender. The sample in this research were 30 students of class III in one of elementary schools in Kampar Kiri sub-district.

Data collection technique used in this study was speaking test. Meanwhile, the assessment for speaking skill used is the assessment rubric. Rubric is a scoring guide that describes the criteria which the teacher wants to assess or to grade the student performance outcomes (Nurgiyantoro, 2011). Aspects of speaking skill adapt the opinion of Nurgiyantoro (2011). The 
Jurnal Prima Edukasia, 7 (1), 2019 -22

Elnida Saldaria, Vina Anggia Nastitie Ariawan, Isah Cahyani

aspects of speaking skill consist of linguistic aspect and non-linguistic aspect. Linguistic aspect includes (1) the accuracy of speech; (2) placement of pressure, tone, joints, and duration; (3) diction; (4) the accuracy of the target of the conversation. Non-linguistic aspect includes (1) attitudes; (2) mimic; (3) loudness of sound; (4) fluency; (5) reasoning.

Validity of data in this study used content validity. Content validity indicates to which extent questions, test items, or instruments are capable of representing the overall content or material that should be proportionally controlled (Bordens \& Abbot, 2013). Therefore, the validity of the contents of a test does not have a certain quantity which was calculated statistically but the test is valid based on instrument review. Data analysis is a way that researchers do to process and summarize data accurately. The data were obtained from the results of speaking tests processed through inductive-statistical data analysis techniques (inference). Inductive-statistics (inference) is a technique of data analysis on the sample and the results will be generalized to the population of the samples taken (Santoso, 2015).

\section{Result and Discussion}

Speaking skill has an important role in the birth of future generations who are intelligent, creative, critical and cultured. Through speaking skill, students are able to express their thoughts and feelings intelligently according to the material and situation when they are talking. Speaking skill is also able to form creative future generations so that they are able to speak communicative, clear, coherent, easy to understand. In addition, speaking skill is capable of producing critical future generations because the students have the ability to express ideas, thoughts, or feelings to others in a coherent and systematic manner (Permana, 2015).

This study aims to identify the speaking skill between female students and male students. Researchers compare the students' speaking skill based on linguistic and non-linguistic aspects. The following is a graph along with the description of identify speaking skill of third grade students.

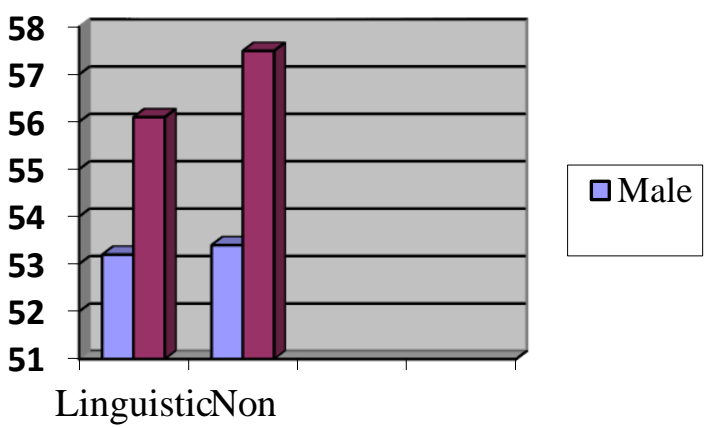

Figure 1. Graph of early speaking skill of third grade students

Figure 1 shows results of speaking skill test of third grade students. The results of speaking skill between female students and male students seem different. Viewed from linguistic aspect, male students earn an average of 53.2 while female students earn an average of 56.1. Viewed from the aspect of non-linguistic, male students earn an average of 53.4 while female students earn an average of 57.5. Overall, the initial speaking skill of female students have the highest average. In addition, the non-linguistic aspect has a better average score than the linguistic aspect. Although the average score of female students' initial speaking skill is higher, the average earnings are still in enough category.

Then, the researchers formulated the research hypotheses to support the results of the calculation descriptively. Research hypotheses in this research are as follows.

$\mathrm{H}_{0}$ : There is no difference in speaking skill between female students and male students in the third grade of elementary school.

$\mathrm{H}_{1}$ : There is a difference in speaking skill between female students and male students in the third grade of elementary school.

Statistic test to calculate research hypotheses was measured by mann-whitney test. Since the value is not normally distributed the researchers continued the hypothesis test using mann-whitney test. The results of the mannwhitney test are listed in table 1 below.

Table 1. Results of Mann-Whitney test

\begin{tabular}{ccc}
\hline Mann-Whitney $U$ & Sig & Result \\
\hline 79,000 & 0,343 & $\mathrm{H}_{0}$ accepted \\
\hline
\end{tabular}

Table 1 shows that the significance value of initial speaking skill of male and female students is 0.343 . The significance value is greater than 0.05 so that $\mathrm{H}_{0}$ is accepted. Based on the results of mann-whitney test, the researchers concluded that there is no difference in speaking 
skill between female students and male students in the third grade of primary school. The finding's research is in accordance with research which have done by Gaer, et al. (2007). The finding's research of Gaer, et al. showed that there is no difference in speaking skill between female students and male students in the fourth grade of primary school. However, female students indicated higher speaking skill rather than male students in some aspects.

Measurement of speaking skill was done by using two ways namely mutual conversations and oral narration. Male students performed better speaking skill and more relax when did mutual conversations than female students. Meanwhile male students are not capable to did oral narration properly. In addition, female students have better oral narration rather than mutual conversations.

That statement is in compliance with finding's research by Erdem (2016) that some students who are succesfull at oral narration can be unsuccessfull at mutual conversations. It caused the students have prepared a topic to speaking at oral narration before so they can speak fluently and notice linguistic rules. Thats why, the students are not capable to share ideas fluently when the situation changes with mutual conversation.

Reviewed by linguistic aspect, female students are good at the accuracy of speech; placement of pressure, tone, joints, and duration; and the accuracy of the target of the conversation. Nevertheless, male students are good at the accuracy of speech and diction. Referring to this research, the students have difficulties to explain their idea so during the period when they haven't got enough vocabulary, they may stay silent or speak with one word sentences. In relation, the students like using mother language when they can not explain their idea.

That obstacles is in compliance with the opinion of Erdem (2017) that some students were using mother language when they are not capable to speak by national language. Therefore, reviewed by non-linguistic aspect female students have good performance on attitudes, mimic, and reasoning meanwhile male students have good performance on loudness of sound and fluency. Gaer, et al. (2007) states that female students performed better than male students did in speaking skill because they (a) felt more socially integrated into the classroom, (b) had better relationships with teachers, (c) were more motivated toward learning tasks, (d) showed higher levels of well- being at school, and (e) had a more positive attitude and mind than male students.

A variety of factors can influence students' speaking skill. Genetic factors, environment, and opportunities for communication affect the speaking skill. This is in accordance with the opinion of Santrock (2009) that learning speaking is influenced by these factors and can also be done through the help of adults through the conversation. In the conversation there is a twoway communication, from the speaker as the sender and the receiver as the idea receiver.

Referring to the previous explanation, Abidin (2015) explains that there are several factors that influence a person's speaking skill such as (a) sensitivity to phenomena, (b) cognitive ability or imagination, (c) language skill, (d) psychological abilities, (e) performance capability. Sensitivity to phenomena is a factor related to students' skill to make a phenomenon a source of ideas. Phenomena can be in the form of events, things, or anything that is tangent to humans. This phenomenon is then captured by students as a stimulus. The process of catching ideas can be done through various activities such as seeing, hearing, reading, feeling, researching, trying, or knowing. This research does not aim to test a learning strategy. Therefore, stimuli obtained by students from researchers or teachers are less than optimal.

The next factor is cognition or imagination skill. Students who have good cognition and imagination skill more easily determine the topic of conversation. If students capture the source of the idea and then process it using cognition or reasoning, the result is a factual message or idea. Meanwhile, if the source of the idea received is processed with their imagination, the student will involve the internal elements that are in him when speaking. The internal elements in question are beliefs, religion, education, social, cultural, emotional, political, feelings, or views of life. Based on the element of students' ability to process ideas and internal elements, a similar phenomenon can produce various ideas of conversation. In this study, students showed poor cognition and imagination skill. Students tend to talk with general topics and play less imagination (Gardner-Neblett \& Iruka, 2015).

Language ability is the ability of students to package ideas in good and right language. In relation to language factors, students should be able to master all aspects of the language. In addition, this ability is related to the student's speaking organs. Students who experience 
Jurnal Prima Edukasia, 7 (1), 2019 -24

Elnida Saldaria, Vina Anggia Nastitie Ariawan, Isah Cahyani

abnormalities in the sound-producing organs will experience speech barriers. For example, students who have difficulty pronouncing the letter " $r$ " so that the resulting speech becomes less than perfect. In this study, researchers found one student who was less able to pronounce the letter "r" but he could speak quite clearly (Griffin, Hemphil, Camp, \& Wolf, 2004).

Then, the factors that influence students 'speaking skill are psychological abilities related to students' psychology or can be categorized as nonlinguistic aspects of students. Psychological factors such as courage, calmness, and psychological adaptability when speaking become part of the condition need to be mastered by students. If students are able to package ideas well, they may not be able to convey ideas orally because they are disturbed by calm when speaking, nervous, and get pressure when speaking. In research, psychological factors or nonlinguistic aspects become significant factors to influence students' speaking skill. The results of the study indicate that every student has poor self confidence, nervousness, and most students seem nervous and get pressure when speaking (Gardner-Neblett \& Iruka, 2015).

The factors that influence the next students' speaking skill are performance ability. Performance skill is related to the practice of speaking. Students are able to use a variety of speech styles that are appropriate to the situation, condition, and purpose of speaking. Speech style is also related to behavior when students talk like expressions, and the ability to build interactive communication. The results of this study explain that students do not build interactive communication with their friends. They only focus on the material that will be delivered. Therefore, the appearance displayed by students becomes less alive or seems rigid. This is not only influenced by performance abilities but other abilities related to speaking skill (Griffin, Hemphil, Camp, \& Wolf, 2004).

Hurlock (2007) says that language skill especially speaking are inseparable from a number of things that need to be developed in speaking, which are mental and physical preparation to speak, good models to imitate, opportunities to practice speaking, motivation, and guidance. Yusuf (2012) states that there are a number of factors influencing the speaking skill of health, intelligence, socioeconomic status, gender, and family relationships. Marliany (2015) added that the socioeconomic factors of parents are enough to influence students' speaking skill. Parents from middle to upper socioeconomic groups feel that speaking is very important so they encourage children to speak better. Parents correct any wrong words and participate in general family talks.

Mass media such as radio, television, or cellphones can also affect speaking skill. Although the media has a significant influence on speaking skill, parents need to pay attention to the impressions that students watch. Parents need to selectively choose impressions so that students do not imitate bad words or behavior. Reading stories or reading newspapers can also increase students' vocabulary and familiarize students with the correct sentence form. In addition, Beaty (2014) states that students' speaking skill will improve by training with their peers. Speaking skill can improve greatly when there are peers who have better speaking skill or are more eloquent than others.

Speaking skill between male and female students are also influenced by their behavior. Prosocial behavior influences the prosocial behavior of students. Students who have high prosocial behavior are easier to interact with their peers and society. Interaction by students certainly trains their verbal abilities. Students will be able to produce a lot of vocabulary and be more flexible when talking to other people. The low level of students' speaking skill is because they have low prosocial behavior and tend to show aggressiveness. Low student speaking skill result in students being unable to construct sentences, lacking the ability to speak coherently, and not having an interesting speaking idea (Dionne, 2005).

The influence of prosocial behavior on speaking skill is evidenced by Bouchard, Cloutier, Gravel, \& Sutton (2008) in his research on early childhood. The results of the study explain that the prosocial behavior of early childhood influences speaking skill. The influence of prosocial behavior is very strong shown by boys. Boys who are able to mingle with friends, interact, and enjoy playing games are more adept at speaking than boys who lack prosocial behavior. Meanwhile, in girls speaking skill are strongly influenced by the response of the interlocutors. When girls talk to people who respond well, it is easier to share their experiences. However, if the response received by girls is not good then they prefer to be silent or not interested in speaking.

Gender has a considerable influence on students' speaking skill. Female students tend to 
Jurnal Prima Edukasia, 7 (1), 2019 -25

Elnida Saldaria, Vina Anggia Nastitie Ariawan, Isah Cahyani

be more skilled at speaking in various situations. Female students are able to control themselves to speak in context and show a good style of speech. Female students are better to master vocabulary and tell more than male students than the male one. Meanwhile, male students lack mastery in speaking structurally because and do not like talking in formal situations. However, male students are better to melt a serious atmosphere so that the atmosphere in the environment is not so stressful. This helps them to master the topic of conversation (Gardner-Neblett \& Sideris, 2017).

Based on the results of the research that has been described previously, then the teacher needs to develop the students' speaking skill. The teacher needs to direct students to process ideas by involving cognition and imagination skills. Students need to get used to producing creative and authentic topic of speaking. Thus, will help students to possess the topic of speaking because they speak based on their own work. In addition, if students are involved in writing the topic of speaking then they will be used to thinking. On the other hand, students are not only skilled at speaking but also be skilled at writing (Abidin, 2015).

There are several consequences that the teacher needs to do during speaking learning, namely (a) the teacher should direct all students' skills from the acquiring ideas stage to the delivering ideas stade; (b) the teacher becomes a speaking model for students; (c) the teacher offers guidance, direction, and motivation to the students so they are encouraged to practice speaking skill.

Jahja (2014) reveals that forms of developing speaking skill should enable students not only to speak fluently but also to enable them to express their ideas, thoughts, or feelings. Additionally, teacher has important role to gain self confidence of students' speaking skill. Self confidence is one of strong factors that affect speaking skill (Sahin \& Kocer, 2014). Among the forms of developing speaking skill are speaking based on pictures, interviews, and storytelling (Hassunah, et al., 2017).

Heryati (2009) explains that the practice of speaking is done by considering the state of the children both in terms of language ability and thinking ability. If the language ability is still weak, the given speaking assignment is still guiding. For example, students are invited in a simple dialogue, speaking with the stimulus of the picture or reading simple books. As an effort to achieve speaking proficiency, children need to be trained continuously because language is built through habits (Rautenberg, 2013).

Correspondingly, Hardman \& Abd-Kadir (2010) explained that training students to speak does not have to be in a formal context or by discussing scientific matters. Teachers need to have a simple dialogue with students to create friendly conditions so that students will be more comfortable responding to dialogue. In learning, dialogue is not only given by the way the teacher asks students to answer the material.

Teachers can form small discussions to develop students' speaking skill. Discussions are formed that discuss topics relevant to student characteristics so students will be interested in arguing. In this case, the teacher really needs to issue his skill in creating a pleasant climate of discussion. Sometimes the teacher can discuss the latest fashion for female students or discuss soccer matches for male students (Westgate \& Hughes, 2015).

After talking about the light things that match the characteristics of students, the teacher can gradually change the flow of the conversation with cases that require students' skill to think more deeply. The teacher also needs to provide small instructions to help students think that they are easier to find ideas based on the instructions given. The language used by the teacher in speaking must be situational so that students do not feel a gripping aura in the learning process. Teachers can use formal language or more relaxed language so students can understand the use of language in various situations (Westgate \& Hughes, 2015).

\section{Conclusion}

Based on the results of the research that has been described, the researchers concluded that speaking skill of male students and female students have no differences. This is proved by the average value of speaking skill of male students and female students which is in sufficient category. However, male students performed better speaking skill and more relax when did mutual conversations than female students. But, male students are not capable to did oral narration properly.

Reviewed by linguistic aspect, female students are good at the accuracy of speech; placement of pressure, tone, joints, and duration; and the accuracy of the target of the conversation. Nevertheless, male students are good at the accuracy of speech and diction. Therefore, 
reviewed by non-linguistic aspect female students have good performance on attitudes, mimic, and reasoning meanwhile male students have good performance on loudness of sound and fluency.

\section{Refferences}

Abidin, Y. (2015). Pembelajaran bahasa berbasis pendidikan karakter. Bandung: Refika Aditama.

Alexander, R. J. (2012). Neither national nor a curriculum? Forum, 54 (3), pp. 369-384.

Azarfam, A.A.Y., \& Baki, R. (2012). Exploring language anxiety regarding speaking skill in Iranian EFL learners in an academic site in Malaysia. International Journal of Applied Linguistics and English Literature, 1 (2), pp. 153-162.

Beaty, J..J. (2014). Observasi perkembangan anak usia dini (edisi ketujuh). Jakarta: Kencana.

Bordens, K.S. \& Abbot, B. (2013). Research design and methods a process approach. New York: Mc Graw Hill Education.

Bouchard, C., Cloutier, R., Gravel, F., \& Sutton, A. (2008). The role of language skill in perceived prosociality in kindergarten boys and girls. European Journal of Developmental Psychology, 5 (3), pp. 338357.

Boyce, J.S., Morgan, S.R.A, \& Rilley, J.G. (2007). Fearless public speaking. Childhood Education, 83 (3), pp. 142-150.

Buckley, B. (2003). The children communication skill-from birth to five years chapter I early language development. Retrieved from http://www.early-education.org. uk.

Chappell, P. (2014). Engaging learners: Conversation-or dialogic-driven pedagogy? ELT Journal, 68 (1), pp. 1-11.

Ciptarja, B. (2008). How to teach your baby talk. Yogyakarta: Penerbit Andi.

Dionne, G. (2005). Language development and aggressive behavior. In Developmental origins of aggression (Tremblay, R., Hartup, W.W., \& Archer, J) pp. 330 - 352. New York: Guilford Press

Erdem, M.D. (2016). Instructors' opinions about the education on Turkish speaking abilities of Syrian students. The Anthropologist, 24 (2), pp. 541-550.
Gaer, E.V.D., et al. (2007). Impact of attitudes of peers on language achievement: gender differences. The Journal of Educational Research, 101 (2), pp. 78-90.

Gardner-Neblett, N., \& Sideris, J. (2017). Different tales: The role of gender in the oral narrative-reading link among African American children. Child Development. Article Inpress.

Gardner-Neblett, N., \& Iruka, I. U. (2015). Oral narrative skill: Explaining the languageemergent literacy link by race/ethnicity and SES. Developmental Psychology, 51, pp. 889-904

Griffin, T. M., Hemphill, L., Camp, L., \& Wolf, D. P. (2004). Oral discourse in the preschool years and later literacy skill. First Language, 24, pp. 123-147.

Hardman, F. (2008). The guided co-construction of knowledge. In Encyclopaedia of Language and Education (Martin-Jones, M., de Mejia, A., Hornberger, N) pp. 253264. New York: Springer.

Hardman, F., \& Abd-Kadir, J. (2010). Classroom discourse: Towards a dialogic Pedagogy. In The International Handbook of English, Language and Literacy [Wyse, D., Andrews, R., \& Hoffman, J., Eds] pp.154264. London: Routledge, Taylor and Francis

Hassunah A.S., et al. (2017). Continuity in literacy achievements from kindergarten to first grade: a longitudinal study of Arabic speaking children. Reading and Writing, 3 (5), pp. 989-1007.

Heryati, Y. (2009). Penerapan model pembelajaran siswa aktif (student active learning) bagi peningkatan keterampilan berbicara bahasa Indonesia. Disertasi Tidak Diterbitkan. Sekolah Pascasarjana. Universitas Pendidikan Indonesia, Bandung

Hurlock, E. B. (2007). Children development sixth ed, Jakarta: Erlangga.

Hwang, W.Y., et al. (2016). Evaluating listening and speaking skill in a mobile game-based learning environment with situational contexts. Computer Assisted Language Learning, 29, pp. 1-19.

Jahja, Y. (2014). Perkembangan psikologi. Bandung: Alfabeta. 
Jurnal Prima Edukasia, 7 (1), 2019 -27

Elnida Saldaria, Vina Anggia Nastitie Ariawan, Isah Cahyani

Marliani, R. (2015). Psikologi perkembangan. Bandung: Pustaka Setia.

Mulyasa, E. (2012). Manajemen PAUD. Bandung: Rosdakarya.

Nurgiyantoro, B. (2011). Penilaian dalam pengajaran bahasa Indonesia. Yogyakarta: BPFE Yogyakarta.

Permana, E.P. (2015). Pengembangan media pembelajaran boneka kaus kaki untuk meningkatkan keterampilan berbicara siswa kelas II sekolah dasar. Profesi Pendidikan Dasar, 2 (2), pp. 130-144.

Piirto, J. (2011). Creative for 21st century skill. Retrieved from

http://ww.sensepublisher.com.

Rautenberg, I. (2013). The effects of musical training on the decoding skill of German speaking primary school children. Journal of Research in Reading, 38 (1), pp. 1-17.

Sahin, A., \& Kocer, O. (2014). Motivation and strategies in foreign language teaching. In Teaching Turkish as a Foreign Language Theories, Perspectives, Activities [Sahin, A., Ed], pp. 33-47. Ankara.

Santoso, S. (2015). SPSS pengolah data statistik di era informasi. Jakarta: Elex Media Komputindo.

Santrock. J. W. (2009). Educational psychology. Jakarta: Salemba Humanika.

Stanley, N., \& Dillingham, B. (2013). Family storytelling: A powerful parenting strategy for developing intellect, language, literacy, and values. Language Magazine. Retrieved from http://languagemagazine.com/?page_id=6 133

Sugiyono. (2013). Metode penelitian pendidikan pendekatan kuantitatif, kualitatif, dan $R \& D$. Bandung: Alfabeta.

Suharsaputra, U. (2014). Metode penelitian kuantitatif, kualitatif, dan tindakan. Bandung: Refika Aditama.

Tarigan, H.G. (2013). Berbicara sebagai suatu keterampilan berbahasa. Bandung: Angkasa.

Thompson, R., \& Haddock, G. (2012). Sometimes stories sell. When are narrative appeals most likely to work? European Journal of Social Psychology, 42, pp. 99102.

Tsou, W. (2005). Improving speaking skill through instruction in oral classroom participation. Foreign Language Annals, 38, pp. 46-55.

Yusuf, S. L. N. (2012). Psikologi perkembangan anak dan remaja (edisi ketigabelas). Bandung: PT Remaja Rosdakarya.

Westgate, D., \& Hughes, M. (2015). Speaking and listening across the primary curriculum: an entry to improved learning and a focus for CPD. Education 3-13, 43 (5), pp. 565-578. 